Cornell University Law School Scholarship@Cornell Law: A Digital Repository

4-8-2011

\title{
Rewiring Old Architecture: Why U.S. Courts Have Been So Slow and Uneven in Their Take-up of Digital Technology
}

Peter W. Martin

Cornell Law School, peter.martin@cornell.edu

Follow this and additional works at: http://scholarship.law.cornell.edu/clsops_papers

Part of the Courts Commons

\section{Recommended Citation}

Martin, Peter W., "Rewiring Old Architecture: Why U.S. Courts Have Been So Slow and Uneven in Their Take-up of Digital Technology" (2011). Cornell Law Faculty Working Papers. Paper 84.

http://scholarship.law.cornell.edu/clsops_papers/84 


\title{
CORNELL LAW SCHOOL
}

\section{Legal StUdies Research PAPER SeRIES}

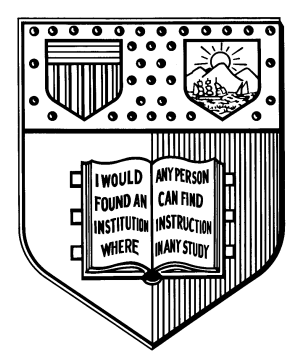

\section{Rewiring Old Architecture: Why U.S. Courts Have Been So Slow and Uneven in Their Take-up of Digital Technology}

\author{
Peter W. Martin \\ Cornell Law School \\ Myron Taylor Hall \\ Ithaca, NY 14853-4901
}

Cornell Law School research paper No. 11-12

This paper can be downloaded without charge from:

The Social Science Research Network Electronic Paper Collection: http://ssrn.com/abstract $=1807188$ 
Last revised 4/8/2011

\title{
Rewiring Old Architecture: Why U.S. Courts Have Been So Slow and Uneven in Their Take-up of Digital Technology ${ }^{*}$
}

\author{
Peter W. Martin ${ }^{\dagger}$
}

Given the centrality of information and communication to the activities and institutions of law and government it is not surprising that during the early turbulent days of the digital revolution enthusiasts imagined that the new technology would work dramatic changes on this critical sphere, changes far greater in magnitude than those flowing from such past innovations as calculators, tape recorders, or copy machines. Students of government and consultants drew analogies between transformations taking place in the private sector (the emergence of e-commerce and distributed, virtual enterprises) and what governments might or should or would become (e-government). Greater efficiency, improved accessibility and performance, and even gains in public accountability were predicted. Judged against such visions and the changes digital technology has brought about in important commercial areas over the past decade, the take-up of digital technology by U.S. courts has been both slow and uneven. This article examines some of the institutional factors that have produced this result. Three applications of the new technology to the work of courts furnish the basis for this investigation. In order, the article examines the extent to which U.S. court systems have: 1) adopted new modes of case citation that are independent of print law reports; 2) assured the availability of adequate and consistent online legal information to judges; and 3) transformed litigation from a process carried out by means of paper filings, paper orders and judgments, held and ultimately archived in official paper records to one reliant on electronic filings and data.

(C) Peter W. Martin, 2011. This work is licensed under the Creative Commons Attribution-Noncommercial-ShareAlike 3.0 License. To view a copy of this license, visit http://creativecommons.org/licenses/by-nc-sa/3.0/ or send a letter to Creative Commons, 543 Howard Street, 5th Floor, San Francisco, California, 94105, USA. An earlier version of the article appeared as a chapter in A HisTORY OF LEGAL INFORMATICS (Abdul Paliwala ed., 2010), available at http://ejlt.org//article/view/16.

$\dagger \quad$ Jane M.G. Foster Professor of Law, Emeritus, Cornell Law School, Ithaca, New York, and cofounder, Legal Information Institute. 


\section{Introduction}

Among the countless " $\mathrm{e}$ " terms to have been coined during the 1990s is "e-government." In 1998 a partner of the Andersen Consulting firm (today known as Accenture) explained "e-government" as the application of the technology and approaches of "e-commerce" to the public sector. ${ }^{1}$ The consequences, she asserted, would be profound: a reduction in the cost of public services, improvement in those services (greater choice, better access), and redeployment of government workers from dull and repetitive tasks to more valuable ones. She also stressed that "to apply the principle of eGovernment successfully, [required] a citizen-centered approach ...."

In the years immediately following, e-government proved to be a growth business area for consulting firms like Accenture. For seven straight years that firm issued a report on the state of e-government implementation around the globe, ranking major countries on the maturity of their programs. ${ }^{2}$ In late 2002 the U.S. Congress passed an "EGovernment Act." 3 The same year the European Union (E.U.) launched an eEurope 2005 Action Plan, ${ }^{4}$ and the E.U. Directorate General for Information Society and Media began issuing periodic surveys that benchmarked the provision of public services online in member states. Scholars began to study and write about e-government.

The aims, purposes, or justifications of these many e-government initiatives include both improvement of government services and cost savings. The latter appear to have been particularly enticing. Where government agencies have succeeded in shifting functions from manual methods to digital, the savings have sometimes been immense. ${ }^{5}$

Many of the early e-government studies focused primarily or even exclusively on transactions taking place or services flowing between public bodies and citizens or businesses. A more comprehensive view of e-government extends to internal government operations. ${ }^{6}$ Public agencies are complex and often very large organizations. Regardless of mission they require systems for managing financial and human resources, for storing, retrieving, and transferring information, for tracking individual cases, for

\footnotetext{
Vivienne Jupp, An Online Government, Business \& FinAnCE (Aug. 13, 1998).

See, e.g., Accenture, eGovernment Leadership: High Performance, Maximum Value (2004). The seventh in this series ended ratings while continuing to provide individual country profiles. ACCENTURE, LEADERSHIP IN Customer Service: Building the Trust (2006).

E-Government Act of 2002, Pub. L. No. 107-347, 116 Stat. 2899 (2002).

See European Commission - Information Society - eEurope 2005,

http://ec.europa.eu/information_society/eeurope/2005/index_en.htm (last visited Apr. 5, 2011).

A Canadian e-government study compared the costs of processing a given transaction. Carried out in person, the cost was Can\$44; by mail, Can\$38; on the telephone (speaking directly to a government worker, not a computer), Can\$ 8 . The online cost was a mere Can\$1. See ACCenture, eGovernment Leadership: High PerformanCe, Maximum VAlue 14 (May 2004). In 2004 the US Social Security Administration estimated that the cost of processing a wage report (form W-2) submitted on paper was $\$ .297$ compared to $\$ .002$ per form transmitted electronically. See OfFICE OF MANAGEMENT AND BUdget, FY 2004 REPORT TO CONGRESS ON IMPLEMENTATION OF THE E-GOVERNMENT ACT OF 2002, at 38 (2005) [hereinafter E-GOVERNMENT ACT REPORT].

6 See Viktor Mayer-Schonberger \& David Lazer, From Electronic Government to Information Government, in GoverNANCE AND InFormation TeChNOlogy: From EleCtronic GOVERnMENT to INFORMATION Government 1, 5 (Viktor Mayer-Schonberger \& David Lazer eds., 2007) [hereinafter INFORMATION GOVERNMENT].
} 
procuring equipment and supplies. Much of the potential for dramatic gains in costeffectiveness from information technology lies here. ${ }^{7}$

Strangely, courts have been largely absent from the e-government movement, literature, ratings and case studies. Although the concept reaches as broadly as government activities range, to postal services, education, health care, and weather forecasting, and has clear relevance to the transactions, services, and internal operations of courts, egovernment enthusiasm and research has been focused almost entirely on the executive and administrative branches. ${ }^{8}$ Since this is true more generally of efforts to adapt approaches first used in the private sector in studying the relationship of organizational structure, culture, technique, and performance to public institutions, ${ }^{9}$ the oversight may be due to a view that courts are so heterogeneous, decentralized, and autonomous as to defy reform or that their missions are too numerous and complex to permit quantitative performance measurement. ${ }^{10}$ Whatever the cause, courts have largely been omitted from the advocacy for and study of e-government.

This is not to say that courts have not been the subject of similarly enthusiastic visions of greater efficiency, improved access, and reduced costs through application of digital technology. Given the centrality of information and communication to core judicial functions and courts' close relationship with private sector intermediaries (lawyers and others) it could not have been otherwise. Since the 1990s and even before U.S. courts have been the site of important technology initiatives. However, whether judged against the expectations that propelled them, e-government successes in other branches of government, or the changes digital technology has brought about in important commercial areas over the past decade, the take-up of digital technology by U.S. courts has been both slow and uneven. This article examines some of the institutional factors that have produced this result.

\section{Three technology-based reforms that crystallized during the late nineteen nineties}

Three applications of the new technology to the work of courts furnish the basis for this investigation. In order, the article examines the extent to which U.S. court systems have: 1) adopted new modes of case citation that are independent of print law reports; 2) assured the availability of adequate and consistent online legal information to judges; and

\footnotetext{
In 2004, using an analytic framework labeled the Federal Enterprise Architecture, the Office of Management and Budget identified five functions or "lines of business" common to most Federal agencies: financial management, human resources management, grants management, case management, and federal health architecture. See EGOVERNMENT ACT REPORT, supra note 6, at 15.

8 Representative is the excellent survey of e-government or e-governance scholarship assembled by Viktor MayerSchonberger and David Lazer. It totally ignores the judicial branch. See InFORMATION GOVERnMENT, supra note 6. An important exception is the U.S. E-Government Act of 2002, which includes provisions addressing the federal courts. See E-Government Act of 2002, Pub. L. No. 107-347, \$S 205-206, 116 Stat. 2899, 2913-16 (2002). Federal court web sites are included in the periodic rankings of states and federal agencies by Darrell M. West, but they do not fare well nor are they mentioned in his analysis. See, e.g., Darrell M. West, State and Federal Electronic GOVERNMENT IN THE UNITED STATES, 2008, at 13, available at http://www.brookings.edu/ /media/Files/rc/reports/2008/0826_egovernment_west/0826_egovernment_west.pdf (last visited Apr. 5, 2011).

9 See, e.g., Brian J. Ostrom, Charles W. Ostrom, Jr., Roger A Hanson \& Matthew Kleinman, Trial Courts as ORGANIZATIONS 7 (2007).
}

10 See id. 
3) transformed litigation from a process carried out by means of paper filings, paper orders and judgments, held and ultimately archived in official paper records to one reliant on electronic filings and data.

\section{A. Medium-neutral citation}

In the U.S. judicial opinions constitute crucial legal authority for judges, lawyers, or anyone else seeking to determine the law on a point or advocating for a particular view. Because of the country's common law heritage they carry particular weight. So long as print was law's dominant publication and research medium, citations to specific opinions and particular passages within them were, quite naturally, based on their location in one or more sets of print law reports. A single commercial publisher of such reports, the West Publishing Company, produced a set (the National Reporter System) that provided comprehensive coverage of all U.S. appellate courts, state and federal. A declining number of jurisdictions also produced or sponsored their own "official reports." In those jurisdictions, lawyers were typically directed by rule or custom to cite by reference to the volume and page numbers of those non-proprietary reports, followed by parallel references to the West volumes.

As online research systems matured, first Lexis and then Westlaw, their designers came to view the inclusion of standard print-derived citation data as critical to market acceptance. Litigation between the two over whether Lexis could insert page numbers drawn from West's reports in its database of opinions without infringing copyright ${ }^{11}$ marked a turning point in their competition. The suit allowed Westlaw to catch up with Lexis and, ultimately, forced Lexis into a costly, though exclusive, licensing agreement. It also yielded a federal appellate court decision supporting West's copyright claim which the company used to threaten a later wave of electronic competitors. ${ }^{12}$ As new forms and sources of digital publication appeared during the 1990s, that litigation stood as a high profile reminder that citation norms tied to West's law books posed a significant barrier to competition.

By the 1990s most courts were producing their opinions electronically and could as a consequence release them in that form. CD-ROM and then Internet publication offered attractive means of increasing competition in law publishing. Cohorts of younger lawyers, trained on Westlaw and Lexis, were conducting case law research without resort to books. These factors led the Supreme Court of Louisiana in 1993 to adopt a new system of citation. It consisted of two key features. First, rather than leave the attachment of citation data to a print publisher the court would embed them in opinions at the time of their release. That meant that publishers (and lawyers) did not have to wait for an opinion's complete and enduring citation until it was assigned volume and page numbers in a print publication. Second, since citation data originated with the court and were bound up with each opinion, they came unencumbered by proprietary claims and could, therefore, be used by any and all publishers, print or electronic. The concept, fiercely opposed by the West Publishing Company, spread quickly, particularly among law librarians who were attracted to the prospect of greater competition in the legal

See West Publ'g Co. v. Mead Data Cent., Inc., 799 F.2d 1219 (8 $8^{\text {th }}$ Cir. 1986).

See Peter W. Martin, Neutral Citation, Court Web Sites, and Access to Authoritative Case Law, 99 L. LiBR. J. 329, 355-57 (2006). 
information market. Serious proposals for medium-neutral citation were brought before several other state supreme courts. ${ }^{13}$ They were refined and endorsed by the American Association of Law Libraries in $1995^{14}$ and the American Bar Association in 1996. ${ }^{15}$ Both organizations advocated strongly for this reform.

The model format emerging from these successive deliberations was straightforward and, for an appellate court at least, easy to implement. It required assigning each opinion a unique identifier consisting of the year, a court designation, and a number. The insertion of paragraph numbers provided a means of citing to specific passages that did not depend on pagination. At roughly the same time, reports advancing comparable schemes of citation reform appeared in Canada, ${ }^{16}$ Australia, ${ }^{17}$ and other common law nations.

During the years immediately following, several states responded to the call. In 1999, drawing on that experience, the chief justices of the nation's appellate courts endorsed a committee report that addressed the issues involved in making the switch. ${ }^{18}$ While declaring that whether any jurisdiction should “adopt such a system” lay outside its scope, ${ }^{19}$ the report's overall message was encouraging.

\section{B. Judicial access to online legal information}

By 1990 two comprehensive online libraries of primary law sources were on offer in the U.S., Lexis and Westlaw - on offer and beginning to supplant print resources. By the mid-1990s large firm lawyers were accessing Lexis or Westlaw from their desktops. A 1998 American Bar Association survey established that a majority of those lawyers had come to prefer electronic legal research to print. ${ }^{20}$ The same year Westlaw and Lexis moved to the World Wide Web. That enabled them to present most, if not all, the value delivered by print format in conventional law reports. ${ }^{21}$ The standard browser interface, plus full-text search, an ability to move from citations to the referenced document with a point and click, immediate access to a citator, and numerous other advantages of the digital environment rapidly and inexorably pulled lawyers and judges away from print libraries. Unconstrained by the economic and spatial limits of book publication, these two systems also gathered and offered decisions that did not circulate in print. At the

\footnotetext{
See id. at 329-40.

Task Force on Citation Formats, Am. Ass’N Of Law Libraries, Final Report (1995), reprinted in 87 L. Libr. J. 580 (1995).

15 See A.B.A. Universal Citation Resolution (1996), available at http://replay.waybackmachine.org/20080725064242/http://www.abanet.org/tech/ltrc/research/citation/resolution. html (last visited Apr. 5, 2011); SPECIAL Comm. ON CitATION IsSues, AM. BAR Ass’N, RePORT AND RECOMMENDATIONS (1996), available at http://replay.waybackmachine.org/20080725063631/http://www.abanet.org/tech/ltrc/research/citation/report.html (last visited Apr. 5, 2011).

16 See Canadian Citation Comm., A Neutral Citation Standard for Case Law (1999, 2003), http://www.lexum.com/ccc-ccr/neutr/neutr.jur_en.html (last visited Apr. 5, 2011).

17 See Andrew Mowbray, Graham Greenleaf \& Philip Chung, A Uniform Approach for Vendor and Media Neutral Citation - the Australian Experience (2000), http://www2.austlii.edu.au/ andrew/citation.html (last visited Apr. 5, 2011).

18 See Conference of Chief Justices, Report of the Committee on Opinions Citation (1999), available at http://ccj.ncsc.dni.us/ finalrpt.pdf (last visited Apr. 5, 2011).

19 Id. at 2.

20 By 1998 a clear majority of large law firm lawyers preferred doing legal research in electronic format to using print. See Am. Bar Ass'N, , Large Law Firm Technology Survey (1998). See generally Peter W. Martin, Reconfiguring Law Reports and the Concept of Precedent for a Digital Age, 53 VILL. L. REV. 1, 21-22 (2008).

21 See id. at 21, 22 n.113.
} 
same time and, in part, as a consequence, library collections began to erode under the pressure of rapidly climbing prices. Shrinking demand for print fed that climb.

These developments combined with competing offerings from a new set of electronic publishers that focused on the law of individual jurisdictions and the pervasive use of computers in other aspects of law practice had, by the end of the century, placed electronic case research in the hands of a large majority of American lawyers from all segments of the practice. ${ }^{22}$ Patently, judges and those doing legal research for them required equivalent access, and depending on court organization that put pressure on court administrative offices, court law libraries, or individual court administrators to subscribe to online services for them.

\section{Electronic filing and storage of case documents}

Litigation begins with the filing of documents. In a civil suit the initiating document is a complaint; with a criminal prosecution it is an indictment or some other charging document. As the subsequent judicial process unfolds the parties and presiding judge continue to exchange documents with one another - motions, responses, memoranda of law, orders, decisions, and judgments. Together these case documents along with the trial transcript and exhibits make up the official record of a case.

By the late 1990s, the potential gains from converting this paper-based process to an electronic one had become obvious. ${ }^{23}$ Complex cases with vast numbers of documents and multiple parties provided the initial impetus. ${ }^{24}$ Working from a system first developed for a federal district court facing a high volume of complex asbestos claims, the Administrative Office of the U.S. Courts had no difficulty finding additional district and bankruptcy courts willing to participate in prototype development. ${ }^{25}$ By the end of 2000, the Administrative Office had begun installing the resulting new case management system. It included, as integrated components, electronic document storage, the capacity for Internet-based electronic filing, and remote access. The plan, by then, was to extend this “CM/ECF" system to all federal courts. ${ }^{26}$ At the end of 2001, the system was operational in thirty-one. ${ }^{27}$ The potential advantages it furnished all participants in the litigation process - litigants and their representatives, as well as judges and court staff -

22 In 2001 lawyers surveyed by the American Bar Association reported that they relied on electronic media (both online and CD-ROM) for roughly 75\% of their case law research. See 2001 Am. BAR Ass'N, TECHNOLOGy Survey REPORT: OnLine ReseARCH, 61, 75 (2008). Seven years later 96\% of the lawyers of all ages surveyed by the American Bar Association reported that they conducted legal research online. The figure for lawyers under the age of 40 was $100 \%$. Then as in 2001 the dominant use of the fee-based legal research services was case law research. 2008 AMERICAN BAR Association Legal Technology Survey Report V-xii, V-xi (2008).

23 See Mary Micheletti, E-Filing: The Battle for the Courts, Law Office Computing, April-May 1999, at 45-54.

24 See id. at 50.

25 See New Case Management System Under Development, 31 The Third Branch, Oct. 1999, http://www.uscourts.gov/News/TheThirdBranch/99-10-

01/New_Case_Management_System_Under_Development.aspx (last visited Apr. 5, 2011); Federal Courts Turn a New Page: Case Management/Electronic Case Files Systems Bring Greater Efficiency/Access, 35 ThE ThiRd BRANCH, Nov. 2003, http://www.uscourts.gov/News/The'ThirdBranch/03-11-01/Federal_Courts_Turn_A_New_Page.aspx (last visited Apr. 5, 2011).

26 LeÓnidAs R. Mecham, Administrative OfFice of the U.S. Courts, 2000 Report of the Director 22, available at http://www.uscourts.gov/uscourts/FederalCourts/AnnualReport/2000.pdf (last visited Apr. 5, 2011).

27 See 2002 a Break-Out Year for CM/ECF Implementation in Federal Courts, 34 THE THIRD BrANCH, Feb. 2002, http://www.uscourts.gov/News/TheThirdBranch/02-02-01/2002_a_Break-

Out_Year_for_CM_ECF_Implementation_in_Federal_Courts.aspx (last visited Apr. 5, 2011). 
made it an easy sale. These included: a filing process that did not require travel to the courthouse, automated docketing, remote and simultaneous access to case files, a drastic reduction in manual filing, retrieval, and copying for court staff, files and documents that could not be mislaid, and fewer delays. ${ }^{28}$ These benefits not only drove the federal court initiative but led numbers of state courts to begin developing electronic filing systems or to contract with commercial vendors for one. ${ }^{29}$

\section{The subsequent progress of these reforms}

Despite evident promise none of these technology-enabled changes has moved rapidly or evenly through the U.S. courts. Where change has occurred and how is in part a consequence of individual leadership and timing, key variables in a system with authority so widely distributed. More significantly, however, the pattern and pace of these three reforms reflect important structural and cultural features of the U.S. judicial system. Each illustrates distinct elements of that institutional reality.

\section{III.The e-commerce analogy does not readily apply to U.S. courts}

During a period that has seen old patterns and methods pushed aside in such commercial sectors as banking, journalism, entertainment, and markets for numerous consumer items, the sluggish take-up of technology by U.S. courts at first seems striking.

Many factors affect the ability of an organization to incorporate new technology in existing processes and, later, to redesign its work flow, methods of production, and ultimate products and services in light of radical new possibilities. Organizations operating in the commercial sector are pressed to change, some to the point of transformation, by the incentives and discipline of a competitive market. Large profits reward organizations that succeed in harnessing technology to improve internal efficiency, reach a broader market, or craft a totally new service. Their challenge is to convert customer gains into revenue. Where substantial investment is necessary to reap these rewards, capital markets offer the necessary funds. Powerful negative incentives operate, as well. Abrupt decline lies in wait for businesses that cling too long to old methods and organizational structures. Conspicuous e-commerce successes and casualties illustrate these several points.

Most government entities function in a markedly different environment and with much less flexibility. Their internal divisions of function and authority are not so malleable as those in the private sector. Etched in statute or even more indelibly in constitutional provisions, they can be very difficult to rearrange. Roles and practices tend to be deeply entrenched and in the case of agencies central to law largely unexposed to market forces. $^{30}$ In the U.S. a desire for "checks and balances” has favored distributed authority and the capacity to block over efficiency. Distributed authority often results in major

\footnotetext{
Id. See also William A. Fenwick \& Robert D. Brownstone, Electronic Filing: What is It? What Are Its Implications?, 19 SAnta Clara Computer \& High TeCH. L.J. 181 (2002).

29 See Bradley J. Hillis, The Digital Record: A Review of Electronic Court Filing in the United States, 2 J. ApP. PrAC. \& Process 319, 321-22 (2000).

30 See Darrell M. West, Global Perspectives on E-Government, in Information Government, supra note 8, at 18.
} 
collective action problems. ${ }^{31}$ In addition, many gains available through digital technology take the form of public benefits not readily returned to the innovating agency in the form of budget relief or increased revenue. ${ }^{32}$ Finally, even when future cost savings or efficiency gains might induce a commercial enterprise to invest in technology or process redesign, fiscal rigidities and politicians' focus on the short-term may prevent a governmental body from doing so. ${ }^{33}$

Beyond these general characteristics of government, U.S. history and ideology have produced court structures peculiarly unable to respond strategically or systemically to new technology. To begin, as the leading text on America's courts explains:

Properly speaking, there is no such thing as the American judicial system. Instead, there are multiple systems, each independent of the others. ${ }^{34}$

This is true most conspicuously because of the coexistence of a set of federal courts in parallel with fifty state court systems. The distribution of authority, administration, and finance of U.S. courts continues further, however; for within many states local units of government hold key responsibility for the judicial function.

Until quite recently no American state had a centrally administered and funded court system comparable to that of the federal courts. ${ }^{35}$ The courts to be found in most states had haphazard and frequently overlapping jurisdiction, a consequence of their having been established at different times to meet different needs. Although trial court decisions were, generally, subject to appellate review, in other respects individual courts operated as autonomous units. Typically, funding and management of appellate courts occurred at the state level. Trial courts were tied to local governments (counties, cities, and other municipalities). ${ }^{36}$ To quote another authority on U.S courts:

Judicial localism served important purposes in a rural, frontier society marked by sharp regional differences and by an isolated parochialism reinforced by primitive transportation. Up to the 1960s, the courts fitted easily into the framework of local government and often acquired distinct local characteristics. ... In every state, there were significant differences in the level of local expenditures for courts due to local economics and labor markets, crime levels, and views about staffing and judicial programming. ${ }^{37}$

The second half of the Twentieth Century saw movement toward "court unification” reform that took many forms and that, by any definition, remains unfinished. ${ }^{38}$

31 See Victor Mayer-Schőnberger \& David Lazer, The Governing of Government Information, in INFORMATION GOVERNMENT, supra note 6, at 281, 282.

32 Edwin Lau, Electronic Government and the Drive for Growth and Equity, in INFORMATION GOVERNMENT, supra note 6, at 39.

33 See David Lazer \& Maria Christina Binz-Scharf, It Takes a Network to Build a Network, in INFORMATION GOvERNMENT, supra note 6 , at $261,262$.

34 DANiEL J. MEAdOR, AMERICAN COURTS 1 (2d ed. 2000).

35 "Unlike the federal courts, which achieved a highly compact organizational structure before 1900, state courts well into [the 20th] century, had a very chaotic organization with a number of local variations in both structure and mode of operation.” Robert W. Tobin, Creating the Judicial Branch: The Unfinished Reform 52 (2004).

36 See Lawrence Baum, American Courts: Process and Policy 40-41 (5th ed. 2001).

37 TOBIN, supra note 35 , at 51.

38 The most complete treatment of the court unification movement signals this conclusion in its title. ROBERT W. TOBIN, Creating the Judicial Branch: THE Unfinished Reform (2004). Another author writes: "[A]dministrative centralization is far from complete across the country as a whole. Not surprisingly, the degree of centralization differs a great deal from state to state and from one area of court governance to another." BAUM, supra note 36, at 49. 
Unification did not necessarily connote central administration and funding. A 1972 study identified only seven states "in which all judicial costs [were] funded by the state through a single budget administered by the judicial branch." ${ }^{39}$ While the numbers have grown since, the traditional pattern of trial court finance - revenues flowing from multiple sources including major local government funding, fragmented financial management and infrastructure support - remains dominant. ${ }^{40}$ Moreover, states that have moved to assume greater administrative and fiscal responsibility have quite commonly begun with judicial salaries and closely related personnel costs, leaving such items as local law libraries, ${ }^{41}$ court clerks and other support staff, and court facilities for a later day. By 2003 the number of states that funded at least ninety percent of their trial court costs had only risen to nine. The trial courts of another sixteen were "substantially state funded." Those of eight more received the majority of their funding from the state but retained local funding for major areas. ${ }^{42}$

Another distinguishing feature of U.S. judicial structure is the doctrine of "separation of powers." At both federal and state levels, law-making, interpreting, and applying authority are conceived of as being divided among three nominally equal branches of government. Despite numerous qualifications and complicating dependencies, U.S. courts, state and federal, operate independently of the legislative and executive branches of government. This independence is at its height on questions of how the judicial function should be carried out - the precise zone where digital technology has such potential for immediate and dramatic reform.

Judicial independence notwithstanding, U.S. courts are without taxing authority. They are, therefore, to an important degree dependent on legislative bodies for funding. Inadequate budgets are a frequent refrain in discussions of judicial improvements of all kinds. Faced with inadequate public funding, courts have at times turned to the private sector, in effect, extracting rents from their monopoly control of a key public function. Court fees are the most obvious form. Others are less conspicuous. The practice of securing public resources under exclusive contracts for publication of "official” reports, for example, has a long history. ${ }^{43}$ Once entrenched, "partnerships" of this kind can become major impediments to change.

\section{Appellate judges as change agents - Medium- neutral citation}

Although deeply embedded in professional practice, citation norms are, in theory, subject to top-down revision, even in highly decentralized court structures. The type of citation

39 Geoffrey C. Hazard, Jr., Martin B. McNamara \& Irwin F. Sentilles, Comment, Court Finance and Unitary Budgeting, 81 YALE L.J. 1286, 1293 (1972).

40 Local finance is generally tied to significant involvement in local politics and, not infrequently, to patronage. See id. at 1297. This is accentuated in many U.S. jurisdictions by the election of judges, court clerks, and other participants in the justice system.

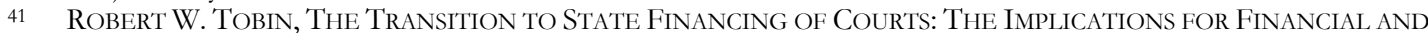
Personnel Management 6 (1981)

42 Susan Byrnes, State Funding of Trial Courts: Minnesota's Transition Experience 20, 54 (2004), http://www.ncsconline.org/d_icm/programs/cedp/papers/ResearchPapers2004/Byrnes,Susan.pdf (last visited Apr. 5, 2011).

43 See, e.g., In re Head Notes to Opinions, 43 Mich. 640 (1881). 
reform urged on America's courts in the 1990s necessitated but two steps. First, a court issuing decisions that others might wish to cite had to adopt the practice of designating each opinion with a unique identifier and attaching paragraph numbers or some other form of print-independent designation to opinion sections. Second, the jurisdiction's rules of practice had to be revised to require use of new system in legal papers submitted to its courts. Both actions reside comfortably within the formal authority of America's courts of last resort, federal and state.

In a minority of American states the only judicial opinions that constitute binding authority and therefore call for citation are those rendered by its highest court. The more common pattern is to have an intermediate appellate court that also issues citable opinions. Normally, though, the procedures of such a court are regulated by the jurisdiction's top court. (The Twentieth Century effort to unify state court systems included at a minimum increased supreme court rule-making authority.) ${ }^{44}$ Most rules of appellate procedure specify how court opinions and other legal sources are to be cited in briefs, memoranda, or similar filings. In sum an American jurisdiction's citation norms can be changed by a combination of appellate court action and fiat, without need for legislative or executive involvement.

Limited budgets are not a serious obstacle. Once courts have begun to prepare and release their decisions in electronic format, the addition of citation data to them should generate no additional expense. The American Bar Association pressed its recommendations on the nation's top courts as something they could quite simply do.

Nonetheless, the proposed reform seemed a wrenching change to many individual judges, one justified solely on the basis of diffuse and intangible public benefits. They saw no direct near-term benefit for courts. Since prior decisions could not be cited by the new system, gains of any consequence lay years away. Comfortable with the status quo, including the dominant role of the West Publishing Company, judges tended to view other problems as far more pressing. 45

Effectuating the reform required altering not only how judges' wrote opinions but the work processes of others. A switch to medium-neutral citation demanded that secretaries, court clerks, and reporters of judicial decisions shoulder new responsibilities and adopt new practices (attaching sequential numbers to decisions and paragraphs within them). The Association of Reporters of Judicial Decisions passed a resolution opposing medium-neutral citation. ${ }^{46}$ It argued that change was unnecessary for jurisdictions with official reports. Concern about staff resistance was an important factor in Louisiana's use of docket numbers as case identifiers. The Supreme Court of Washington, pressed to adopt citation reform, delegated the assignment of case and paragraph numbers to the publisher of its print reports, thereby nullifying most of the scheme's value. Resistance from court staff was reported to be a reason. In 1997 the Administrative Office of the U.S. Courts surveyed the views of all federal judges and court clerks on the American Bar Association citation proposal. Although the majority of the responding judges were

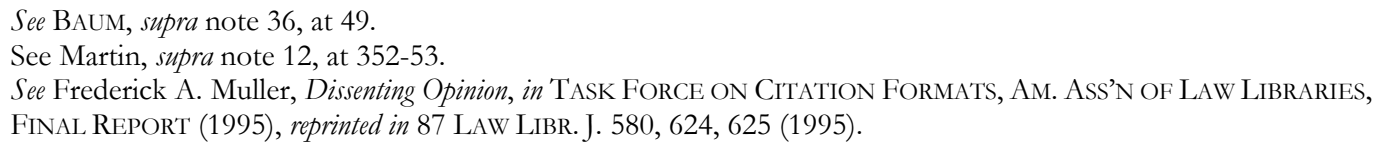


opposed, there were some supporters in this group. ${ }^{47}$ The responding clerks were uniformly negative. They saw the proposal as thrusting "an entirely new 'editorial role"” upon them at a time when they were in need of more resources and better technology to support “core responsibilities". 48

Faced with serious internal resistance and seeing no direct and immediate benefits for themselves or court staff, American appellate judges have not rushed to adopt mediumneutral citation. The federal courts have, so far, shown no movement; and only fourteen state courts (slightly more than a quarter) have implemented the change in some form. ${ }^{49}$

What factors set the adopting jurisdictions apart? First, in nearly all cases the reform had an internal champion. But there are distinguishing structural features, as well. Most adopting jurisdictions had, years before, ceased to produce state-funded law reports and eliminated the public office dedicated to their production. This meant both the absence of a potential source of internal opposition and greater awareness of the gains likely to flow from fostering greater competition for the West Publishing Company's reports. Further while the vast majority of the fifty states, like the federal courts, have two-tier appellate structures, eleven have only a single appellate court. Six of these are among the states that have adopted medium-neutral citation. Nine of the fourteen adopting jurisdictions have state trial court systems with fewer than 100 judges, half have fewer than $60 .{ }^{50}$ Six are in the bottom quintile of states ranked by population and number of lawyers; only three rank in the top half by these measures. ${ }^{51}$ In sum, the courts embracing this change have been, on average, those of smaller states, possessing simpler judicial systems.

Two professional groups pressed for citation reform - lawyers and librarians. Both sought to break the competitive advantage that print-based citation gave the dominant publisher of law reports. States with bar groups that encompass and speak with a single voice for all lawyers in the jurisdiction have been more likely to adopt neutral citation, ${ }^{52}$ as have jurisdictions where the high cost of legal information for courts at all levels is the concern of a single state official, in the state law library or administrative office.

47 For the text of the responses to the survey, see HyperLaw, Comments to Judicial Conference re Citation Reform March/April 1997, http://www.hyperlaw.com//jccite/jconf.htm (last visited Apr. 5, 2011). For a summary with comments, see HyperLaw Report - Judicial Conference Public Comments (March 24, 1997),

http://www.hyperlaw.com//jccite/jcmail.htm (last visited Apr. 5, 2011). See also Coleen M. Barger, The Uncertain Status of Citation Reform: An Update for the Undecided, 1 J. App. Prac. \& Process 59, 80-81 (1999).

48 Doherty, Memorandum (Feb. 28, 1997), http://www.hyperlaw.com//jccite/014.txt (last visited Apr. 5, 2011).

49 They are Arkansas, Louisiana, Maine, Mississippi, Montana, New Mexico, North Dakota, Ohio, Oklahoma, South Dakota, Utah, Vermont, Wisconsin, and Wyoming. See Peter W. Martin, Basic Legal Citation \2-230 (2010), available at http://www.law.cornell.edu/citation/; Peter W. Martin, Abandoning Law Reports for Official Digital Case Law, Cornell Legal Studies Research Paper No. 11-01 (Jan. 25, 2011), available at http://ssrn.com/abstract=1743756.

50 See National Center for State Courts, Examining the Work of State CourTs 22 (2010), available at http://www.ncsconline.org/d_research/csp/2008_files/EWSC-2008-Online\%20Version\%20v2.pdf.

51 U.S. Census Bureau, State Rankings - Resident Population (July 2009), http://www.census.gov/compendia/statab/2011/ranks/rank01.html (last visited Apr. 5, 2011); Am. Bar Ass'n, National Laywer Population by State (2006), http:// http://www.americanbar.org/content/dam/aba/migrated/marketresearch/PublicDocuments/2009_NATL_LAWYE R_by_State.authcheckdam.pdf (last visited Apr. 5, 2011).

52 Twenty-eight states ( $56 \%$ of 50 ) have so-called unified bars. They include nine of the thirteen states that have adopted medium-neutral citation. See Wikipedia, Bar Association, http://en.wikipedia.org/wiki/Bar_association (last visited Apr. 5, 2011). 
At the other extreme, a handful of populous states with large numbers of lawyers and complex court systems represent sufficiently important legal information markets that the major commercial players, West and LexisNexis, are willing to produce their "official" law reports at no cost, offering tangible returns to the judiciary for this designation and its accompanying unique access to official citation data together with the final, official text of opinions. States where the judicial branch has this sort of economic stake in the status quo, most notably California and New York, have shown no inclination to change over to a citation system that would undermine the exclusivity bestowed by their public-private "partnership.", 53

\section{Reform by government purchase - Meeting trial court legal research needs}

Unlike citation reform computer-based legal research has moved into most U.S. courthouses. Even where cases must still be cited by volume and page numbers, judges and others who assist their research now access their texts, together with those citation parameters, online. An obvious difference between the two reforms is that the benefits of this one are immediately and directly experienced by the judiciary. At least equally important, these are benefits that can quite simply be bought.

Until recently print law libraries, generally located at the courthouse, met judges' legal research needs, although not always adequately or evenly throughout a jurisdiction. As lawyers migrated from physical law libraries to virtual ones, it became increasingly obvious that judges should be furnished equivalent access. This was not a point on which most judges or court support staff needed persuasion. Economies of scale available through bulk purchase, having all judges throughout a jurisdiction working from the same data, and coordinating training and support pointed toward dealing with this requirement on a jurisdiction-wide basis. The principal impediment was that in many states the funding of library support for trial judges was a local government responsibility.

That, of course, was not the pattern in the federal courts. The Administrative Office of the U.S. Courts proceeded in 1998 to subscribe to Westlaw on behalf of the federal judiciary. The same year it accepted a free subscription to Lexis. ${ }^{54}$ Ever since both legal research services have been available to all federal judicial personnel. ${ }^{55}$ In those few states with fully unified court budgets and administration, the question "Who should contract and pay for this new service?” similarly posed no difficulty. Their structure placed securing Westlaw or Lexis services for trial judges, including the decision whether to select a single provider or give all judges a choice, in the hands of state-level judicial administrators. ${ }^{56}$

See Martin, supra note 12, at 349-52.

Leónidas R. Mecham, Testimony Before the Subcomm. on Courts and Intellectual Property, House Comm. on the Judiciary (June 11, 1998) (LEXIS).

55 LeÓnidas R. Mecham, Administrative OfFice of the U.S. CourTs, 2004 RePORT OF THE Director 38, available at http://www.uscourts.gov/uscourts/FederalCourts/AnnualReport/2004.pdf (last visited Apr. 5, 2011).

56 Accordingly, all trial court judges in Alaska, Connecticut, Kentucky, and Hawai'i are covered by Westlaw contracts. See Peter W. Martin, How State Courts Contract for Legal Information, http:/ /www.access-to-

law.com/elaw/ct_CALR/contracts.htm (last visited Apr. 5, 2011). 
State-level purchase of online services has also occurred, however, in numbers of states that retain significant local funding of trial courts, including their library costs. ${ }^{57}$ Why should state court administrators assume this cost while leaving others to be borne by local government? For any state judicial branch progressing toward greater levels of state funding this was an attractive target. It had no history of local support. County law libraries faced with rapidly rising costs were not eager to cover this new one. The state's taking it on neither threatened jobs nor intruded upon existing institutional turf. To statelevel judicial administrators it presented the type of trial court cost that could be assumed with minimal difficulty. It was relatively small in amount, ${ }^{58}$ not open to local manipulation, and predictable. So long as an online service could be obtained at a fixed price per password, its cost scaled with the number of judges on a court. By the late 1990s both Lexis and Westlaw were prepared to offer court subscriptions on such terms.

Even in states where decisions about online research services and their costs remain with local districts, state court administrators have been able to assist. In 2000 the Texas Office of Court Administration secured blanket contracts from both Westlaw and Lexis under which individual courts could subscribe. ${ }^{59}$ Montana took a further step. At a time when the cost of trial court online research was still borne by Montana counties, the state law library entered into a lump sum contract with Lexis that provided sufficient passwords for the entire judiciary. The library offered them to all judges and judicial staff in the state for a pro rata share of the overall fee. This framework pushed the cost back on district courts and allowed each court to decide whether to participate. Montana trial courts were free to subscribe instead to Westlaw, but the rate differential induced a pronounced migration to Lexis. Then, in 2003 the state moved to assume trial court costs. The new funding formula distinguished between pre-existing commitments and fresh ones in a way that increased the incentive for districts with other arrangements to switch to the state law library contract. ${ }^{60}$

Significantly, however, there are still numbers of states in which judicial access to online legal research is not assured - a direct consequence of leaving responsibility for this matter with each district or county and not providing state-level funding. ${ }^{61}$

\section{Inducing coordinated change in court systems with dispersed administrative authority - Moving to electronic document submission and storage}

The conversion of court filing and document storage from print to electronic media presents a more complicated story. Unlike citation reform this change cannot be accomplished by appellate court action and mandate alone. Its very success depends on

\footnotetext{
57 States in this group include: Idaho, Mississippi, Missouri, and South Carolina. See id.

58 The New York Judiciary's 2007-08 budget request illustrates the comparatively small cost associated with this item. The line item for computer assisted legal research services for the state's trial courts totaled $\$ 281,281(.05 \%$ of the total budget request of nearly $\$ 524$ million). The separate law library component of the budget was nearly 30 times that amount. New York Unified COURT SYSTEM, 2007-08 Judiciary BudGET ReQUeST, http://www.nycourts.gov/admin/financialops/Bgt07-08/07-08budgetwhole.pdf (last visited Apr. 5, 2011).

59 See Texas Courts Online: Office of Court Administration: Legal Research Contract Documents, http://www.courts.state.tx.us/contract/contractdocs.htm (last visited Apr. 5, 2011).

60 Telephone interview with Judy Meadows, State Law Librarian, Montana (Jan. 31, 2007).

61 Examples include: Georgia, Kansas, Nevada, Ohio, Pennsylvania, and Texas. See Martin, supra note 56.
} 
major work redesign at the trial court level. Unlike extending online legal research service throughout a court system, it involves far more than purchasing a standard commercial offering. Furthermore, since this reform touches on the entire litigation process, its requirements vary enormously according to the scale and character of an implementing court's caseload. A system designed to meet the needs of a single-judge court handling fewer than one hundred filings a year or a municipal court processing a few thousand traffic violations, together with collection of fees, may be totally unsuited to the caseload of a large urban court, with fifty or more judges, and hundreds of thousands of filings a year. ${ }^{62}$

Conversion requires the persuasion and training of lawyers as well as judges. Actually, the key public actors are not judges but the court staff responsible for receiving, storing, and distributing litigation documents, and later furnishing on-demand access to the resulting court records. Consequently, the budgets, incentives, human resources, and institutional setting of these officials bear critically on the possibilities for and shape of any conversion from paper to electronic media.

Long before pervasive electronic filing became possible, court clerks had introduced a diversity of computer-based systems - to support case scheduling, to keep track of the contents and location of paper files, and to account for the fines, fees, and costs assessed in litigation. Some had acquired scanning systems to meet the challenge of document storage. As a consequent of different choices made at different times by districts with quite different needs, any coordinated move to electronic filing and document storage by a jurisdiction was near certain to have implications for a wide array of legacy data systems. Close relationships with system vendors, some of whom offered electronic filing as an add-on to existing administrative software, easily led court personnel to place a higher value on integration with what they already had in place than compatibility with systems chosen by others.

On this front, several factors placed the federal courts at a distinct advantage. Their caseloads are far less diverse than those handled by state systems. Unlike state courts they had long received centralized funding and backup administrative support. Their clerks and other staff are employees who serve only the courts. They are also civil service employees rather than elected officials or political appointees. Many of the existing computer information systems in the trial-level district and bankruptcy courts were designed and supported by the Administrative Office of the U.S. Courts. These factors together with effective and timely leadership by the Administrative Office, ample funding to invest in new systems, ${ }^{63}$ and a clear system-wide plan made it possible for the federal courts to achieve an electronic filing, document storage, and records access system no state has yet come close to matching.

62 For an illustration of the immense range compare the case activity of the Texas district courts for Loving and Harris counties during fiscal year 2010. See District Courts: Case Activity by County, TeXAs Judicial System AnNuAL REPORT FISCAL YEAR 2010, http://www.courts.state.tx.us/pubs/AR2010/dc/6-district-activity-by-co-sorted-by-pop.pdf (last visited Apr. 5, 2011).

63 Some of this funding came from capitalizing on the market value of the data held in federal litigation records, particularly those of the bankruptcy courts. See Peter W. Martin, Online Access to Court Records - from Documents to Data, Particulars to Patterns, 53 VILL. L. REV. 855, 860-72 (2008). 
Launched on a court-by-court basis, the federal Case Management/Electronic Case Filing $(\mathrm{CM} / \mathrm{ECF})$ system is now in place across all district and bankruptcy courts, as well as all regional courts of appeal. ${ }^{64}$ The nature of bankruptcy litigation has produced a system capable of dealing with voluminous filings and a multitude of parties. By anticipating rather than lagging the needs of individual courts, the federal Administrative Office was able to achieve this result through leadership, service, and support rather than mandate. ${ }^{65}$

CM/ECF's success was not inevitable nor is it yet unqualified. At the time work began on the software that became the CM/ECF system, several federal trial courts had already established electronic document storage systems on their own. ${ }^{66}$ The range of court requirements and existing practices forced the Administrative Office to adopt a highly configurable design. This increased the difficulty of installation and training and continues to challenge inter-court compatibility. Finally, tolerance of judicial autonomy has allowed individual judges to insist that in matters over which they preside, all electronic filings must be accompanied by the parties' delivery of tangible "courtesy" copies to their chambers. ${ }^{67}$

In most states, court autonomy has presented a far more serious obstacle. Explaining the slow progress of electronic filing in one state, two commentators wrote:

The state courts are typically structured so that each local court has its own case management system, unique rules, and methodology, making it difficult for practitioners to operate consistently from court to court in the same state. A balkanized environment can make it difficult to establish a uniform e-filing system - not only because of local rules and systems, but because funding for courts is typically on a local basis as well. ${ }^{68}$

Incompatible legacy software is a major problem. A planning document prepared by California's Administrative Office of the Courts counted more than 200 case management systems in the state's fifty-eight counties, all configured differently. It reported further that many California courts lacked the financial and technology resources to build their own electronic filing systems and that the state administrative office hadn't the capacity to develop one for state-wide use. ${ }^{69}$

Much of the day-to-day support of the litigation process is carried out by officials with the title of clerk and their employees. They receive case filings, maintain case records,

64 See James C. Duff, Annual Report of the Director, Administrative Office of the United States Courts 33 (2010), available at

http://www.uscourts.gov/uscourts/FederalCourts/AnnualReport/2010/images/annualReport2010.pdf.

65 Even within the framework of the federal court system mandates dealing with court operating procedures typically address each and every individual court through its chief judge and leave room for local variations. See E-Government Act of 2002, Pub. L. No. 107-347, \205, 116 Stat. 2899, 2915 (2002).

66 See Micheletti, supra note 23, at 47.

67 Local Rule 5.2(f) of the District Court for the Northern District of Illinois requires a paper copy of each electronically filed pleading, motion, or document to be provided for the judge to whom the matter is assigned within one business day unless the judge determines otherwise. Most judges provide on their individual Web sites that the paper copy must be delivered directly to their chambers within that time frame. See Helen W. Gunnarsson, Lawpulse, ILL. BAR J., July 2008 , at 334 , n 336.

68 Joseph H. Firestone \& James C. Horsch, Are You Ready for e-Filing, Michigan BAR J., Oct. 2005, at 22, 23.

69 This text appeared on an e-filing "Concepts" page at the California Courts Web site as early as August 2002. See the Internet Archive Wayback Machine,

http://waybackmachine.org/*/http://www.courtinfo.ca.gov/programs/efiling/concepts.htm (last visited Apr. 5, 2011). 
and distribute court rulings, but often carry other public responsibilities as well. While one might assume that in performing court-related functions clerks are supervised by and answerable to judges, the reality in many states is far more complex. The very first legal issue addressed in a 2005 report of a Florida Committee on Privacy and Court Records was whether clerks were subject to the supervision and rule-making authority of the state supreme court. Although the committee concluded that they were, the issue demanded serious attention. ${ }^{70}$

In well over half the states, clerks are elected. ${ }^{71}$ It is not uncommon for the office to be set out in a state's constitution. ${ }^{72}$ Even more than trial court judges, clerks have, historically, been closely connected to local politics and government. Possessing staff of their own and an independent political base, clerks have been known to play a key role in judicial election campaigns. ${ }^{73}$ Even at the state level they can be an effective political force. In Oklahoma, district court clerks secured legislative action blocking an effort to establish a single state-wide case management system. ${ }^{74}$

Because of such institutional factors, state court implementation of electronic filing remains spotty and, in general, lags far behind the level achieved in the federal judiciary. One might expect this with states where local governments retain substantial administrative and funding responsibility for trial courts. But even in states at the other end of the spectrum, with state money furnishing nearly all trial court support, electronic filing has progressed slowly because of the complexity and cost of the conversion process. Of the nine states that fund $90-100 \%$ of trial court costs, only two (Connecticut and Vermont) have rules authorizing electronic filing. ${ }^{75}$ In Connecticut the rule is accompanied by a mature electronic filing system that is not merely available for use in most civil matters filed in the state's trial courts but mandatory. ${ }^{76}$ Vermont only launched optional electronic filing in two trial courts in late 2010, with a plan to extend it to the rest by the end of 2011. ${ }^{77}$ The Massachusetts trial courts are well along in implementing an integrated, state-wide case management system, but electronic filing remains a distant goal. ${ }^{78}$

70 See Supreme Court of Florida, Comm. on Privacy and Court Records, Privacy, Access and Court Records 119-22 (2005), available at http://www.floridasupremecourt.org/pub_info/documents/privacy_4.pdf (last visited Apr. $5,2011)$.

71 Writing in 2001, one authority counted 40 states in which trial court clerks are elected. BAUM, supra note 36 , at 48.

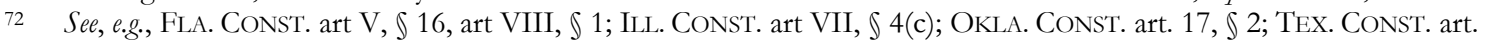
$5, \int 9$.

73 See ToBIN, supra note 35 , at 72.

74 Telephone interview with Kevin King, former MIS Dir., Okla. Sup. Court (June 2, 2006).

75 CONN. Rules \ 4-4; VT. R. ELECTRONIC FiLING.

76 See State of Connecticut Judicial Branch, Welcome to e-Filing, http://www.jud.ct.gov/external/super/eservices/efile/default.htm (last visited Apr. 5, 2011); CONNECTICUT JUDICIAL BRANCH, BIENNIAL REPORT AND STATISTICS 2008-2010, at 32, available at http:/ /www.jud.ct.gov/Publications/BiennialReport2008-10.pdf (last visited Apr. 5, 2011).

77 See State of Vermont Judiciary, Electronic Services, eCabinet Electronic Filing, http://vermontjudiciary.org/MasterPages/eservices-efiling.aspx (last visited Apr. 5, 2011).

78 See Roberta Holland, "MassCourts" Launch Promises Ease, Efficiency for Courts, Lawyers, Public, MBA LAW. J., Dec. 2006, at 6, available at http://www.massbar.org/media/117319/li_dec_v27.qxd.pdf (last visited Apr. 5, 2011); Roberta Holland, MassCourts Computer System, No Longer a "Leap into the Unknown," Proves to be a Practical Solution, MBA LAw. J., Dec. 2006, at 6, available at http://www.massbar.org/publications/lawyers-journal/2008/january/masscourts-computer-system,no-longer-a- $\% \mathrm{E} 2 \% 80 \% 9$ Cleap-into-the-unknown, $\% \mathrm{E} 2 \% 80 \% 9 \mathrm{D}$-proves-to-be-a-practical-solution (last visited Apr. 5 , 2011). 
In several other states with less complete but nonetheless substantially centralized trial court funding and administration, electronic filing is a work in progress. New Jersey's JEFIS program offers electronic filing to civil litigants in matters with $\$ 15,000$ or less at stake. $^{79}$ By mid-2011 use of the system will be mandatory for all firms initiating 400 or more such matters in a year. ${ }^{80}$ New York has a system that is currently operational for all case types in two counties, for commercial, tort, and tax cases in fifteen more. ${ }^{81}$ Its use is mandatory for high stakes commercial litigation in one court. ${ }^{82}$ North Carolina's $^{\text {' }}$ specialized trial court unit handling complex commercial and corporate litigation offers and encourages the use of electronic filing. ${ }^{83}$ After testing electronic filing with appeals, ${ }^{84}$ the Alabama Supreme Court launched it in the state's trial courts. ${ }^{85}$ By 2011 it was being used in nearly all civil cases and some criminal matters. ${ }^{86}$

There is one important sense in which the high courts of all states have control over electronic filing implementation in their jurisdictions. For it to take place they must amend procedural rules historically framed in terms of paper documents. As of 2007, roughly half the states had rules opening this door. ${ }^{87}$ They include those establishing state-wide systems discussed above, but also states in which the new rules merely set the terms and conditions on which trial courts can, if they elect and employing such systems as they choose, allow electronic filing. The initiative, system selection, and other crucial details may be left to each individual court. Arizona is a state in which a substantial portion of trial court funding comes from local governments. ${ }^{88}$ Its electronic filing rule exemplifies this approach. It reads in part: "The presiding judge of the superior court in each county may permit by appropriate court rule the electronic filing of documents in the superior court and justice courts in each county." 89 Pursuant to this authority the Maricopa County Superior Court (Phoenix) has implemented electronic filing. ${ }^{90}$ Electronic filing is not generally available in Arizona nor are other courts that might take advantage of the rule required to adopt compatible systems.

79 See JEFIS - Statewide Judiciary Electronic Filing System, http://www.judiciary.state.nj.us/jefis/index.htm (last visited Apr. 5, 2011)).

80 See JEFIS Special Civil Part- DC Docket, http://www.judiciary.state.nj.us/jefis/scp_dc.html (last visited Apr. 5, 2011)).

81 See NYS Unified Court System - Filing by Electronic Means, https://iapps.courts.state.ny.us/fbem/mainframe.html (last visited Apr. 5, 2011).

82 See MEF-Notice to CD, http://www.nycourts.gov/supctmanh/MEF-Notice\%20to\%20CD.pdf (last visited Apr. 5, 2011).

83 See North Carolina Business Court, http://www.ncbusinesscourt.net/ (last visited Apr. 5, 2011); North Carolina Business Court Local Rule 6.1, available at http://www.ncbusinesscourt.net/New/localrules/NCBC\%20Amended\%20Local\%20Rules\%20-\%202006.doc (last visited Apr. 5, 2011).

84 See Appellate Court Electronic Filing Project (2005), http://replay.waybackmachine.org/20090221034652/http://www.judicial.state.al.us/efiling.cfm (last visited Apr. 5, 2011).

85 See E-Filing, http://efile.alacourt.gov/ (last visited Apr. 5, 2011).

86 See Chief Justice's State of the Judiciary Address, http://www.wsfa.com/Global/story.asp?S=14212980\&clienttype=printable (last visited Apr. 5, 2011).

87 John T. Matthias, E-Filing Expansion in State, Local, and Federal Courts 2007, Future Trends IN STATE COURTS 2007, at 34, available at http://www.ncsconline.org/WC/Publications/Trends/2007/ELFileTrends2007.pdf (last visited Apr. 5, 2011).

88 See Byrnes, supra note 42, at 20.

89 ARIZ. Sup. CT. R. 124(a).

90 Superior Court of Arizona in Maricopa County, Electronic Filing Guidelines, https://efiling.clerkofcourt.maricopa.gov/efilingguidelines/ (last visited Apr. 5, 2011). 
A few states have used rules authorizing electronic filing and electronic court records to guide adopting courts toward a common interface or data standard. This approach doesn't bring electronic filing to impoverished or reluctant parts of the jurisdiction but it does lay the foundation for what may, eventually, become a state-wide system. At roughly the same time, both California and Texas headed down this path.

In 1999 the California Administrative Office of the Courts began work on technical standards for electronic filing. ${ }^{91}$ Building a state-wide system at that point seemed impossible. By 2002, the project had achieved both a conceptual model and specifications for an ultimate system toward which commercial service providers and trial courts could aim. ${ }^{92}$ Progress since then, however, has been slow and intermittent. ${ }^{93}$

Confronted with individual court initiatives and the likelihood of incompatibility, the Texas Judicial Branch adopted a model that sets standards for commercial electronic filing service providers, who provide the interface, training, and support required by filers, and for court case and document management systems. ${ }^{94}$ This pair of standards is embodied in state-sponsored infrastructure known as "TexasOnline." The state's Judicial Committee on Information Technology provides model rules for both county and district courts that implement this electronic filing arrangement. ${ }^{95}$ (Local electronic filing rules must be approved by the Texas Supreme Court. $)^{96}$ Court systems must be capable of receiving filings passing through TexasOnline. Litigants filing electronically may employ any one of several commercial service providers whose systems have been certified for compatibility with the TexasOnline infrastructure. ${ }^{97}$ Filers must have accounts with and pay a "transaction fee" to TexasOnline, in most cases a "convenience fee" to the court, and also the charge of their chosen service provider. In total these average \$10 per filing, in many cases far less than the expense of physical delivery to a court clerk. $^{98}$ As of March 2011, only 47 of the 254 Texas counties were participating, but these included the major metropolitan areas, accounting for approximately seventyfive percent of the state's population. ${ }^{99}$

91 California Courts: Programs: Electronic Filing in California,

http://waybackmachine.org/*/http://www.courtinfo.ca.gov/programs/efiling/ (last visited Apr. 5, 2011).

92 California Courts: Programs: Electronic Filing in California: Concepts,

http://waybackmachine.org/*/http://www.courtinfo.ca.gov/programs/efiling/concepts.htm (last visited Apr. 5, 2011); California Courts: Programs: Electronic Filing in California: Standards,

http://waybackmachine.org/*/http://www.courtinfo.ca.gov/programs/efiling/standards.htm (last visited Apr. 5, 2011).

93 So slow, in fact, that the state has, in effect, altered its course. The Administrative Office continues to work on a standard case management system that will eventually be installed in all of California's trial courts. See Administrative Office of the Courts, Fact Sheet, Court Case Management System (CCMS) (Jan. 2011),

http://www.courtinfo.ca.gov/reference/documents/factsheets/CCMS.pdf (last visited Apr. 5, 2011). An electronic filing component remains an ambition, but only that.

94 See Peter Vogel \& Mike Griffith, Electronic Court Filing: The Texas Model, http://www.courts.state.tx.us/jcit/Efiling/pdf/TheTexasModel.pdf (last visited Apr. 5, 2011).

95 JCIT: Electronic Filing - Home Page, http://www.courts.state.tx.us/jcit/Efiling/EfilingHome.asp (last visited Apr. 5, 2011).

96 Tex. R. Civ. P. R. 3 a.

97 The current list is online at http://www.texas.gov/en/tx-efiling/Pages/getting-started.aspx (last visited Apr. 5, 2011)..

98 See Peter Vogel \& Mike Griffith, supra note 93, at 4; Texas.gov | eFiling for Courts: Frequently Asked Questions, http://www.texas.gov/en/tx-efiling/Pages/faq.aspx (last visited Apr. 5, 2011).

99 Texas Online, Electronic Court Filing, Jan. 2011, http://www.courts.state.tx.us/jcit/Efiling/pdf/efiling_map.pdf (last visited Apr. 5, 2011). 
Colorado started out along an altogether different route to comprehensive and uniform state-wide electronic filing, namely, outsourcing. In January 1999, the Colorado Judicial Department contracted for commercial creation and operation of a complete system. Its initial vendor was acquired by LexisNexis in 2001. Colorado's agreement with LexisNexis CourtLink placed electronic filing and the resulting digital case files totally in the control of the contractor. While the state retained "ownership" of all Colorado documents held in the LexisNexis "File \& Serve" system ${ }^{100}$ and had, upon contract termination, the right to download them to its own servers, ${ }^{101}$ so long as the contract continued LexisNexis held complete responsibility for the electronic filing system, document storage, and data access. ${ }^{102}$ A huge attraction of the arrangement to the state judiciary was that it carried no direct budgetary cost. The state paid nothing to LexisNexis. Actually, monies flowed the other direction. LexisNexis collected and remitted the state's standard filing fees for all documents filed electronically. ${ }^{103}$ In addition it paid the state a modest amount per transaction. ${ }^{104}$ A 2005 contract renewal brought a lump sum payment of $\$ 160,000$ to the Colorado court system. ${ }^{105}$ Use of LexisNexis "File \& Serve" by judges and judicial staff, other state personnel, and courtappointed and funded representatives incurred no charge. ${ }^{106}$ All training and support costs were borne by LexisNexis. ${ }^{107}$ The entire system has been financed by additional electronic filing fees collected by LexisNexis from those who use it - all litigants other than the state - and its charges for ancillary services. ${ }^{108}$ Under the Colorado contract, the company's fees for electronic filing and service are subject to state approval, but its charges for add-on features and for public access to documents in the LexisNexis system are not. ${ }^{109}$ The LexisNexis framework produced a single electronic system now in use throughout the state and mandatory for a majority of civil case types in most of Colorado's judicial districts. ${ }^{110}$ Well over ninety percent of the documents in civil matters that can be are now filed electronically. ${ }^{111}$ However, the state's relationship with LexisNexis is scheduled to end with the expiration of the current contract in 2012. The state's judicial department plans to have its own electronic filing and document management system in place by then. The Colorado legislature approved the substitution in 2010. ${ }^{112}$ Its proponents emphasized that like the commercial system it will replace this state-built and state-run electronic filing framework should require no expenditure of

100 See State of Colorado Judicial Department, Second Renewal of Agreement for Services $\ 11$ ("Right to Sell Documents") (June 6, 2005) (on file with author).

101 See id. $\$ 18(C)$ ("Post-Termination Requirements").

102 See id. $\$ 3$ ("Specifications of EFile Service").

103 See id. \$ 12 ("Collection of Filing and Other Court Fees").

104 See id. \$8(D) ("Compensation").

105 See id. S 8(D)(iv) ("One-time Fee”).

106 See id. $\$ 8$ (C)(iii), (iv).

107 See id. \$S 3(F) ("Training”), 3(K) ("Help Desk and Other Technical Support").

108 See id. at 2 ("WHEREAS, no payment of public funds to the contractor will be required to carry out the project ....").

109 See id. SS 8(B)(ii) ("Premium Service Features"), 8(C)(ii) ("Premium Service Features"), 11 ("Right to Sell Documents").

110 See Colorado Judicial Branch, Mandatory E-File Courts (Jan. 2010), http://www.courts.state.co.us/userfiles/File/Mandatory\%20E-File\%20Courts\%202010.pdf (last visited Apr. 5, 2011).

111 See Coloardo Judicial Branch, E-Filing, http://www.courts.state.co.us/Administration/Program.cfm?Program=21 (last visited Apr. 5, 2011).

112 See ICCES Oversight Committee, Minutes of Meeting, Oct. 22, 2010, http://www.courts.state.co.us/userfiles/file/Efiling\%20oversight\%20committee\%20102210.pdf (last visited Apr. 5, 2011); Colorado General Assembly, Joint Budget Committee, FY 2011-12 Staff Budget Briefing $20-24$ (Nov. 11, 2010), http://www.state.co.us/gov_dir/leg_dir/jbc/judbrf.pdf (last visited Apr. 5, 2011). 
taxpayer dollars. Funds for its design and construction are to come from revenues generated by fees paid by commercial data resellers for access to the contents of Colorado's state-wide case management system. ${ }^{113}$ Once operational the filing and document management system will be sustained by fees for use similar to those charged by LexisNexis, although ultimately, it is hoped, significantly lower. This is an ambitious plan with a tight schedule. If it succeeds Colorado will have brought in house a mature, fully implemented electronic filing system initially established under a "no cost to the court” outsourcing framework.

The outsourcing of public functions, including those traditionally managed by courts, is neither new in the U.S. nor, it seems, politically controversial, at least so long as the work remains within the country. ${ }^{114}$ This is especially true of functions that require new technology. Outsourcing can seem particularly attractive in this context. It offers a way for courts to acquire technology and related expertise without heavy upfront investment. Indeed, the LexisNexis contract with Colorado demonstrates how by granting the commercial partner the capacity to charge filers and those seeking access to court data and documents outsourcing can be accomplished without expenditure of taxpayer funds. Outsourcing also appears to lower the stakes by reducing the difficulty of adjusting a course of action in response to future needs and developments, as Colorado is presently attempting to do. ${ }^{115}$ However, by leaving court data in the custody of a private firm, outsourcing the full process of electronic filing and document management opens a completely new set of issues. Furthermore, by financing the scheme through a contractor's charges the state judiciary is, at minimum, assuming major regulatory responsibility. While the Texas model also includes commercial service providers, it limits their role to providing interface, training, and support to filers. They are permitted to charge for the service, but those charges are constrained by competition. Competition also protects the state against vendor lock-in, a serious risk with the original Colorado model. In addition, reliance on a commercially maintained electronic filing and document storage system is likely to frustrate full integration with court-based case management software, functionality that the federal CM/ECF system has achieved and toward which Colorado and numerous other states are striving.

Delaware has followed Colorado down the outsourcing path, contracting with LexisNexis for electronic filing and document management services in support of the state's trial courts, its Chancery Court, and the Delaware Supreme Court. ${ }^{116}$ The approach has also been embraced by individual courts in jurisdictions that have not addressed electronic filing on a state-wide basis. In some instances this has led to legal challenges based on both Constitutional and state law grounds. These tend to be fueled by lawyer concern

113 See ICCES Oversight Committee, supra note 111; Colorado General Assembly, Joint Budget Committee, supra note 111, Appendix D.

114 Many courts now outsource fee collection and other judgment compliance functions, some on a statewide basis. See Gordon M. Griller, The Growth of Outsourcing: Courts Are Becoming Flatter, in FuTURE TRENDS IN STATE COURTS 18 (2009), available at http://contentdm.ncsconline.org/cgi-bin/showfile.exe?CISOROOT=/hr\&CISOPTR=143 (last visited Apr. 5, 2011).

115 See id.; Gina Belisario-McGrath, Information Technology Outsourcing From a Court Perspective (2000), http://www.ncsconline.org/d_icm/programs/cedp/papers/Research_Papers_2000/Information\%20Technology\%20 Outsourcing.pdf (last visited Apr. 5, 2011).

116 See Electronic Filing in the Delaware Judiciary, http://courts.delaware.gov/efiling/index.stm (last visited Apr. 5, 2011). 
over the substantial fees imposed by the service provider, particularly when applied in matters where electronic filing is mandatory. ${ }^{117}$

\section{Timing, scale, and the pursuit of standards}

\section{A. Timing}

Following an initial cluster of adoptions, the movement of U.S. jurisdictions toward medium-neutral citation seems to have lost momentum. The professional organizations that advocated for this reform during the 1990s shifted their attention to other issues. Electronic publishers have proliferated and prospered despite the cost and inconvenience of accommodating print citation norms. Might it be that the moment for this reform has passed? Several factors suggest otherwise. First, working models of medium-neutral citation in over a quarter of the states should put concerns about the cost or difficulty of implementation to rest. In contrast, they also highlight the functional difficulties caused by the continued need in other jurisdictions for publishers or researchers to secure volume and page numbers, data derived from books that are themselves rarely used. Most U.S. appellate courts now offer a decade or more of past decisions at a public Web site. As the those collections grow ever deeper so may the embarrassment to courts of having to refer users to printed law reports for the "official version" and citation information. When this embarrassment coincides with significant public expenditure on the production of those law reports the combination can be compelling. ${ }^{118}$ Finally, the availability in electronic format of vast numbers of opinions that cannot be cited to print because they will never be published in that form should generate increasing pressure for court-attached citation information.

The movement toward comprehensive judicial access to online legal information, already far ahead of the implementation of medium-neutral citation, has not slowed. On this front, as well, the electronic dissemination of decisions not published in print is a propelling factor. In those many jurisdictions now allowing citation of such decisions, access to them by all judges should appear a necessity. That access can be assured only by state-level measures.

Due to path dependence, time promises to play a more complex role in the shift from paper to electronic filing. In May 2008, the chief justice of the Illinois Supreme Court, speaking on behalf of the Court, announced a plan to link all that state's trial courts electronically. According to his statement, the system would, once completed, enable electronic filing throughout all 23 judicial circuits and 102 counties in Illinois. ${ }^{119}$ Five years earlier the Illinois Supreme Court had authorized electronic filing on an experimental basis subject to state administrative office supervision. ${ }^{120}$ Nonetheless, the Court's 2008 announcement was greeted with scepticism. Wrote the Illinois Bar Journal:

117 See McPeters v. Edwards, No. 4:10-cv-1103, 2011 U.S. Dist. LEXIS 8397 (S.D. Tex., Jan. 27, 2011); McCurdy v. Fulton County, No. 2010 CV- 1797571 (Ga. Super. Ct. Fulton County, Dec. 1, 2010)

118 See Martin, supra note 49.

119 Chief Justice Robert R. Thomas Announces E-Business Initiative for Illinois Courts, http://www.state.il.us/court/media/PressRel/2008/052308.pdf (last visited Apr. 5, 2011).

120 See Policy for Implementation of an Electronic Filing Pilot Project in Illinois Courts, http://www.state.il.us/court/SupremeCourt/Policies/Pdf/Efiling.pdf (last visited Apr. 5, 2011). 
“[E]xactly what to expect, or when, or how, remains unclear.... [C]osts and funding sources for the initiative are yet uncertain." ${ }^{121}$ The announcement itself acknowledged those issues and also conceded that one conspicuous path was no longer open. While the Administrative Office of the U.S. Courts had been able a decade before to attach its electronic filing initiative to the replacement of obsolete case management systems, Illinois could not. That was because by 2008 its trial courts had in place a diversity of functioning case management systems which the envisioned state-wide system could not displace. $^{122}$ Illinois is a state where localities still furnish a majority of trial court funding, clerks hold significant political power, and counties range in population from over 5 million to under 5 thousand. ${ }^{123}$ Realizing the Supreme Court's electronic filing vision will be a far greater challenge now than if the effort had begun a decade ago. By 2011 only five counties out of the state's 102 had received Court approval for electronic filing, and no single, compatible service reached them all. ${ }^{124}$

In states like Illinois where local courts or clerks are free to make indepedent decisions about case management software, delay in establishing state-wide electronic filing increases the difficulty of the endeavor. States that have gone further and allowed individual courts to establish or contract for electronic filing systems on their own, without taking steps to assure interoperability, may find it nearly impossible to achieve a uniform system covering the entire jurisdiction.

\section{B. Scale}

Electronic filing's promise of significant public gains and its attractiveness as a source of revenue to commercial providers depend on scale. The numbers work for trial courts like that in King County (Seattle), Washington (population 1.8 million). Since converting to electronic court records, King County has reduced court administrative staff by 18.5 positions. (A further trimming of 7.5 is projected.) Reduced expenditures for space and supplies generate additional annual savings of approximately $\$ 250,000 .^{125}$ LexisNexis has made the numbers work for Fulton County, Georgia (population 1 million) and Colorado (population 5 million). ${ }^{126}$ Courts serving much smaller populations with very little litigation, if considered individually, yield quite different results. In states that leave responsibility for trial court administrative support on local units of government, electronic filing will be a long time coming to sparsely populated rural areas.

Texas and Washington are two such states. Both have successful models of electronic filing in major population centers. Texas has set of standards that apply throughout the

\footnotetext{
See Gunnarsson, supra note 56, at 336.

See Thomas, supra note 119.

123 See State and Local Funding for the Illinois Courts, http://www.state.il.us/court/General/Funding.asp (last visited Apr. 5, 2011). In 2009 the population of Cook County (Chicago) was 5.3 million, that of Pope County, 4.0 thousand. Illinois QuickFacts from the U.S. Census Bureau, http://quickfacts.census.gov/qfd/states/17000.html (last visited Apr. 5, 2011).

124 See Ann Knef, E-filing Launched in St. Clair County Circuit Clerk's Office, MAdison County Record (Oct. 20, 2010); Illinois E-Filing, http://www.state.il.us/court/ebusiness/efiling.asp (last visited Apr. 5, 2011).

125 See King County, Wash., Electronic Court Records Honored as Innovations in American Government Award Winner, GoverNMENT TECHNOLOGY, http://www.govtech.com/security/King-County-Wash-Electronic-Court-Records.html (last visited Apr. 5, 2011).

126 These and subsequent population figures are for the year 2009. They are drawn from U.S. Census Bureau, State \& County QuickFacts, http://quickfacts.census.gov/qfd/index.html (last visited Apr. 5, 2011).
} 
state. But working models and standards will not bring electronic filing to Loving County, Texas (population 45) or Garfield County, Washington (population 2,101). In such settings, the potential gains from electronic filing and remote access to the resulting court records for judges, individual litigants, and their representatives should be large, but because of the small numbers total savings to the public purse are not likely to place this high on the list of local funding priorities. Geographic inequity is the inevitable result. By cumulating benefits as well as costs across courts and local units of government jurisdictions that plan and fund conversion to electronic filing at the state-level can avoid this consequence of inadequate scale.

\section{Standards}

States that leave all critical decisions about electronic filing implementation to individual courts virtually guarantee adoption of incompatible systems. That creates a future problem for any effort to unify state courts and an immediate one for lawyers who practice law beyond a single locality. An early California electronic filing report noted that a large percentage of lawyers in that state practice in at least four counties. The report concluded it was important to have a single system that could be used by lawyers filing in any kind of case before any court in the state. ${ }^{127}$

While the pattern of trial court funding in Texas may make state-wide electronic filing a distant prospect for that state, it has, at least, established a framework that assures interoperability. Working through the state-certified electronic service provider of their choice, lawyers need master and use a single interface as they represent clients before state trial courts in Austin, Dallas, Houston, or San Antonio. The requirements set for qualifying court case management systems lay a foundation for state-level indices, data extraction, and analysis. Both results have been achieved through use of the state supreme court's rule-making authority to establish state-wide standards.

Looking beyond the courts of individual states to those of the federal courts and neighboring jurisdictions, the prospects of wider interoperability (one system allowing filing with most U.S. courts through the service provider of one's choice) seem dim. That is not for want of reasonable standards but is due instead to the absence of any agency with sufficient authority or influence to secure adherence to them. Timing, too, has been a problem. In 2003 a committee of state court judges, administrators, and technical personnel named the "National Consortium for State Court Automation Standards” produced an electronic filing standard. ${ }^{128}$ A more detailed set of technical standards prepared under the auspices of the "LegalXML" project has been a work in progress for at least seven years. ${ }^{129}$ While both have proven influential with a number of

127 California Courts: Programs: Electronic Filing in California: Concepts, http://waybackmachine.org/*/http://www.courtinfo.ca.gov/programs/efiling/concepts.htm (last visited Apr. 5, 2011).

128 The National Consortium for State Court Automation Standards, Standards for Electronic Filing PROCESSES iii (2003), available at

http://www.ncsconline.org/d_tech/standards/Documents/pdfdocs/Recommended_\%20Process_\%20standards_02_ 26_03.pdf (last visited Apr. 5, 2011).

129 An April 2002 report of the U.S. General Accounting Office referred to the promise of this initiative but noted that it had not yet completed any specifications. GAO, ELECTRONIC GOVERNMENT, GAO-02-327, at 41-42, available at http://www.gao.gov/new.items/d02327.pdf (last visited Apr. 5, 2011). Work on the specifications continues. See 
states, neither was available in time to guide the designers of the federal courts' CM/ECF system.

Standards have also proven both attractive and elusive in the realms of citation and legal research. Operating within so complex and a decentralized legal system, lawyers and judges have long been drawn toward products, procedures, or norms that moderate the difficulty of researching the law of so many jurisdictions and citing authority from so many courts.

The original success and subsequent staying power of the commercially produced National Reporter System, while partly a consequence of its comprehensive coverage, was also due to its providing the case law of all state and federal courts in a consistent format, indexed according to a single topical matrix, and citable according to a standard formula. The wide influence of a citation manual published by a small group of law journals, nominally for their own use, reflects the same strong desire for a national citation standard. ${ }^{130}$ Numbers of state courts have asserted their own requirements for citation of cases, but most either complement or largely incorporate these unofficial national norms. ${ }^{131}$

The efforts of the American Association of Law Libraries (AALL) and American Bar Association (ABA) on citation reform were not limited to arguing that courts should adopt some form of medium-neutral citation. The name of the ABA resolution and the subsequent AALL guide make it clear that both organizations sought a "universal" system - a consistent approach to citation reform across U.S. jurisdictions. However, since this "universal" system could be achieved only by incremental action, jurisdictionby-jurisdiction, it was inevitable that diverging implementations would result even among those accepting the premise of the reform. Although a national medium-neutral citation standard would be enormously useful, its emergence from an extended sequence of independent acts by state high courts and the federal judiciary is most unlikely. ${ }^{132}$

Any publisher can, of course, attempt to establish a new national citation scheme. In fact, both Westlaw and Lexis have. Being proprietary, however, their electronic citations communicate effectively only with those using the same service. U.S. v. Greer was decided on April 7, 2011 by the United States Court of Appeals for the Ninth Circuit. Lexis designated the opinion "2011 U.S. App. LEXIS 7063.” Westlaw initially provided a similar citation in the format "2011 WL 1312575." Were the decision not to be published in the Federal Reporter it would retain that designation, but since it is to be "published" the Westlaw citation will be replaced by the decision's volume and page

OASIS LegalXML Electronic Court Filing TC, http://www.oasis-

open.org/committees/tc_home.php?wg_abbrev=legalxml-courtfiling (last visited Apr. 5, 2011).

130 The Bluebook: A Uniform System of Citation (2010).

131 See, e.g., FlA. R. App. P. 9.800; IOWA R. App. P. 6.14(5); 11TH Cir. R. 28-1(k).

132 Two states that have adopted medium-neutral citation illustrate the difficulty of achieving national uniformity. Louisiana adopted a neutral citation scheme in 1993, years before any national organizations had formulated a

"universal" system. It is highly unlikely that the intangible gains from uniformity will move Louisiana courts and lawyers off their now firmly established system. In Ohio neutral citation did not arrive until 2002. However, because the scheme was designed and implemented by the state's reporter of decisions, whose publication responsibilities extend to a highly decentralized intermediate appellate court, and selected trial court decisions rather than by the courts themselves, it employs a sequence number that does not distinguish among those courts as the ABA's "universal" system would. The decision designated "2007-Ohio-4843" was handed down by the Supreme Court of Ohio; "2007Ohio-4844" identifies a decision of the Eight Appellate District Court of Appeals. 
numbers in that print publication when it appears. And because current citation norms dictate use of that print citation Lexis will, in due course, add it alongside its electronic citation. Unfortunately, a Lexis citation will not retrieve a case on Westlaw (or Loislaw or Fastcase or any of the other commercial online services), and Westlaw citations work only on Westlaw. The case for court applied medium-neutral citations is that they work across media and commercial systems. The continued attraction of the National Reporter System citations for cases published in its pages and of Westlaw and Lexis citations for "unpublished" cases loaded in their services is uniformity across courts.

\section{Conclusion}

To anyone working within a less decentralized, more coherently administered, judicial system, the picture presented here must appear chaotic or worse. Individually, U.S. courts have embraced technology. They have acquired computers and word processing software for judges. Many have turned to the Web as a cost-effective means of communicating information about location, schedules, and procedures. Court rules and widely used forms are posted at court sites. And most judges in most U.S. jurisdictions have access to a sophisticated online legal research service. But reforms that depend on coordinated action or substantial investment are progressing more slowly and far more unevenly than they might in a more unified system. Because of the uneven pace, dispersed initiative, dependence on other government actors, widely different legacy systems, entrenched work practices and commercial interests, some outcomes seem not merely distant but unlikely. It is hard to conceive of this country's courts converging on a uniform medium-neutral citation scheme or constructing electronic filing systems that would enable attorneys to operate within the same computer environment and use the same procedures whether litigating in federal or state court. Indeed, for many states a uniform state-wide system of electronic filing and online document access seems an "impossible dream." 